\title{
DIVERSIFICATION OF CUSTOMER SHOPPING STYLES AS A RESULT OF CHANGES IN THE WEEKLY WORK SCHEDULES OF RETAIL OUTLETS
}

\section{DYWERSYFIKACJA STYLOW ZAKUPOWYCH KLIENTÓW W KONTEKŚCIE ZMIAN W TYGODNIOWYM ROZKKADZIE PRACY PLACÓWEK HANDLU DETALICZNEGO}

\author{
Piotr Cyrek, PhD \\ University of Rzeszów, Collegium of Social Sciences, Institute of Economics and Finance, \\ Poland, ul. Ćwiklińskiej 2, 35-601 Rzeszów \\ piotrcyr@univ.rzeszow.pl oORCID: 0000-0002-8306-1612
}

DOl: 10.2478/minib-2020-0016

\section{ABSTRACT}

The article presents the results of three studies conducted by the author concerning the preferences of retail outlet customers with regard to the days of the week on which they most frequently purchase general food and non-food merchandise. This issue has become relevant within the context of the enactment of the Act of 10 January 2018 on limiting trade on Sundays, holidays and certain other days. Previous customer shopping styles as regards weekly shopping schedules must have changed. The aim of the article is to identify consumers' habits and their changes concerning the weekly shopping schedules before and after the Act implementation. The results are based on direct surveys conducted in 2014, 2016 and 2018 among customers in Podkarpackie Province. A descriptive analysis of the results is supported by the statistical test chi square usage. It may be concluded that both in relation to food and non-food merchandise, the implementation of the Act resulted in a decrease in the number of customers engaging in shopping on Sundays. In the case of food items, the shopping activity moved to Mondays and Tuesdays of the following week, the purpose being to resupply. No increase was identified in the number of customers purchasing food on Fridays or Saturdays preceding nontrading Sundays. The opposite was true for non-food merchandise, where non-trading Sundays resulted primarily in increased sales on Saturdays, with minor increases on Mondays, Tuesdays and Wednesdays as well. The differences in weekly shopping schedules observed between every edition of the study also proved to be more significant than those identified in the individual respondent classification groups used for the purpose of the article.

\section{Key words: trade, consumers' behaviour, shopping days, trade on Sundays}




\section{ABSTRAKT}

W artykule zaprezentowano wyniki trzech edycji własnych badań preferencji klientów placówek handlowych dotyczących dni tygodnia, kiedy realizują główne zakupy produktów ogólnospożywczych oraz przemysłowych. Zagadnienie to nabrało znaczenia w kontekście wprowadzenia 10 stycznia 2018 r. Ustawy o ograniczeniu handlu w niedziele i święta oraz w niektóre inne dni. Dotychczasowe style zakupowe klientów wyrażone tygodniowym rozkładem zakupów musiały ulec zmianie. Celem artykułu jest identyfikacja zwyczajów konsumenckich w zakresie tygodniowego rozkładu realizacji zakupów i ich zmian w okresie przed wprowadzeniem ustawy i po jej wprowadzeniu. Wnioskowanie oparto na wynikach wywiadów bezpośrednich przeprowadzonych w 2014, 2016 i 2018 roku wśród konsumentów w województwie podkarpackim. Analiza opisowa otrzymanych wyników została uzupełniona wykorzystaniem statystycznego testu chi kwadrat. Przeprowadzone badania wskazują, że w przypadku produktów zarówno żywnościowych, jak i przemysłowych ustawa faktycznie ograniczyła odsetek klientów realizujących niedzielne zakupy. W przypadku produktów ogólnospożywczych przenieśli oni swoją aktywność zakupową na poniedziałek i wtorek kolejnego tygodnia, uzupełniając ewentualne braki. Nie odnotowano natomiast wzrostu odsetka osób, które realizowałyby zakupy żywności na zapas w piątek czy sobotę poprzedzające niedzielę niehandlową. Przeciwnie, w przypadku produktów przemysłowych ograniczenie zakupów w niedziele skutkowało ich zwiększeniem głównie w sobotę, choć wzrosty odnotowano także w poniedziałek, wtorek i środę. Różnice w tygodniowych rozkładach zakupów zaobserwowane między kolejnymi edycjami badania okazały się przy tym bardziej istotne niż te odnotowane w poszczególnych grupach klasyfikacji respondentów wykorzystywanych w opracowaniu.

Słowa kluczowe: handel, zachowania konsumentów, dni zakupów, handel w niedziele

JEL: D10, D12, D19, L81, R20, K23

\section{Introduction}

A number of dilemmas arise within the context of the legislation precluding retail outlets from operating on Sundays. These dilemmas concern the process of households being able to successfully resupply with general food and non-food items. The article analyses the changes in habits related to shopping for the above product groups on particular days of the week. Its main aim includes identifying consumers' preferences concerning weekly shopping schedules and changes of such habits between 2014, 2016 and 2018 year. The scale of the changes during and after the enactment of 
the relevant legislation limiting Sunday trade is thus analysed. The hypothesis of this article is that there exist statistically significant differences in weekly shopping schedules between years before and after the entering into force of the act prohibiting trade on Sundays. The necessity to comply with the provisions of the act by both businesses and their customers leads to the adoption of the premise that the changes which occurred in the analysed period (2014, 2016 and 2018) are more pronounced than the differences identifiable in the weekly shopping schedules of the diversified subgroups analysed in the article.

The above premises are verified based on the results of the author's own research conducted in 2014, 2016 and 2018. The data was collected using the direct survey method, utilising the author's own questionnaire, in random locations and retail outlets in Podkarpackie Province. Every tenth customer was surveyed until 10 respondents in total were found in a given shop. The surveys were then assessed to eliminate those which were incomplete. The final number of participants was 787, 611 and 250, respectively. The survey of customers allowed the author to analyse the issue of shopping patterns according to a number of demographic, social and economic criteria, as well as using the dynamic approach. The differences between groups of customers as well as the differences between years under research were tested with the usage of chi square at significance level $\alpha=0,05$.

\section{Literature review}

The legislative changes prohibiting commerce on Sundays were controversial and gave rise to social and political discussions. Economics was used as an instrument in this discourse to provide both sides of the dispute with arguments. Within this context, Sundays were treated as working days (production goods) or rest days (consumer goods), generating opportunity costs of their use in both cases (Drobny, 2015, pp. 110-111). However, the public discussion expanded beyond economic calculations to include more complex, cultural and axiological reasons as to why Sunday should be a rest day. Justifications for prohibiting commerce on Sundays 
were raised as early as at the bill stage, and focused primarily on matters such as resting, religion, private and family life, as well as developing domestic businesses (Strzała, Grygutis, 2018, p. 9). A great number of the prohibition's opponents brought up the economic costs of limiting commerce (presented e.g. in a report by $\mathrm{PwC}$ from December 2016, cf. Szromnik, 2017a, pp. 416-417), as well as the issue of freedom of business. Its supporters, on the other hand, emphasised the necessity to cultivate human and social capital (Dylus, 2013, p. 195), protecting labour rights, the significance of family life and rest, as well as the religious aspects (Adamiec, Grodzka, 2017, p. 1). The issue of public support was also raised, which was seen as necessary for the new regulations to be implemented (Dylus, 2013, p. 199).

Numerous surveys painted an ambiguous picture of public opinion on the prohibition, in addition to indicating that Poles do actually shop for consumer goods on Sundays. As an example, a CBOS study conducted in September 2016 indicated that the majority of Poles shopped on Sundays (79\%) (as cited in Adamiec, Grodzka, 2017, p. 1), which was supported by the results of a study by Ceneo (September 2016), according to which a similar percentage of Poles shopped on that day. According to the results of a study by TNS (October 2016), the majority of Poles (approx. 2/3 of all respondents) did not support the new law (Szromnik, 2017a, pp. 415-418). On the other hand, research conducted by Szromnik (2016) in south-east Poland indicated a dichotomous division of the population regarding the prohibition of trade on Sundays (Szromnik, 2017b, p. 192).

Results of studies on the consequences of implementing the prohibition are also of interest in this context. Data published by the Polish Central Statistical Office indicates that the sales achieved by super and hypermarkets actually increased compared to the year prior during the first month after the act entered into force (as cited in: Jękot, 2018, p. 13). The results of the study on the weekly shopping habits conducted in June 2018, i.e. after the new law entered into force, indicate that most customers preferred to shop on Saturdays. The majority of the respondents were opposed to the prohibition, with only a third of the respondents supporting shops closing on Sundays. In addition, no significant decrease in shopping volume was identified on Sundays - only $1 / 3$ of the respondents did not 
shop on non-trading Sundays (Jękot, 2018, pp. 14-20). However, the number of studies on the changes in weekly shopping cycles is relatively low (Szromnik, 2017a, p. 411). Such research, provided that it considers the long-term outlook, is justified due to the fact that, as pointed out by Dylus (2013, p. 196), the law, in addition to its restricting function, also serves to educate and change attitudes and behaviours in the long term. It is therefore to be expected that the social acceptance of the prohibition will gradually increase, and that the legislatively-determined shopping patterns will eventually change.

\section{Weekly shopping patterns and their changes over time}

Three editions of research conducted among consumers in Podkarpackie Province shed some light on changes in purchasing behaviours in a period of implementation of the Act on limiting trade. Regardless of the period analysed and type of product, the respondents preferred to shop on Saturdays. The reason for this is the greater availability of free time, as well as the traditional approach to organising household chores, according to which Sunday is treated as a rest day. However, the sales volume on Saturdays was higher for non-food merchandise - non-perishables, products which are purchased relatively more rarely, and whose purchasing involves more involvement and risk. Products from this group were also purchased relatively frequently on Fridays, indicating a planned, long-term nature of the decision-making process. In the case of food merchandise, purchases were made much more frequently on Mondays, which is determined by the relatively short shelf life of many types of food and the need to replenish "weekend" supplies.

Despite the significant limitation in the ability to purchase food merchandise on Sundays after the new legislation was introduced, the number of customers shopping on Monday increased only by 3.5 percentage points in 2018 compared to the previous edition of the study (Table 1). A similar increase was identified in the percentage of customers who resupplied on Tuesdays. Wednesday was only slightly affected by the 
implementation of the prohibition on Sunday trading. A significant increase was identified in relation to shopping on Thursdays, which were the least popular days to shop both before and after the law entered into force.

\section{Table 1. Weekly shopping preferences for food and non-food merchandise identified in individual editions of the study (total \%)}

\begin{tabular}{l|r|r|r|r|r|r}
\hline \multicolumn{1}{c|}{ Merchandise } & \multicolumn{3}{c|}{ Food merchandise } & \multicolumn{3}{c}{ Non-food merchandise } \\
\hline \multicolumn{1}{c|}{ Year } & $\mathbf{2 0 1 4}$ & $\mathbf{2 0 1 6}$ & $\mathbf{2 0 1 8}$ & $\mathbf{2 0 1 4}$ & $\mathbf{2 0 1 6}$ & $\mathbf{2 0 1 8}$ \\
\hline Total percentage of respondents & & & & & & \\
$\quad$ customers shopping on: & 100.0 & 100.0 & 100.0 & 100.0 & 100.0 & 100.0 \\
Monday & 22.2 & 20.9 & 24.4 & 9.5 & 7.7 & 10.0 \\
Tuesday & 7.8 & 7.4 & 11.2 & 6.9 & 6.1 & 7.6 \\
Wensday & 6.1 & 9.2 & 9.2 & 6.5 & 7.2 & 11.6 \\
Thursday & 5.2 & 3.8 & 6.8 & 5.8 & 7.0 & 5.2 \\
Friday & 18.8 & 23.4 & 17.6 & 21.7 & 25.9 & 18.8 \\
Saturday & 32.9 & 30.6 & 29.2 & 45.0 & 40.8 & 45.2 \\
Sunday & 7.0 & 4.7 & 1.6 & 4.6 & 5.4 & 1.6 \\
\hline
\end{tabular}

Source: calculations based on results of the own research.

The decrease in the number of respondents selecting Friday and Saturday as their food shopping day is slightly surprising within the context of shops being closed on Sundays. It would appear that the natural consequence of the prohibition should be an increased interest in these two days as an opportunity to amend potential deficiencies. In actuality, however, consumers tended to resupply at the beginning of the following week. This may be indirectly caused by the increased interest in catering services, which is an indication of a social trend, as well as being able to access food establishments on Sundays. The significant decrease in the number of respondents shopping on Sundays is in line with the legislative intention behind the prohibition and is a result of the act entering into force.

A similar trend could be observed in the behaviour of customers shopping for non-food merchandise. Within this context, a slightly 
more pronounced decline in Sunday shopping was identified compared to food products. Monday, Tuesday and Wednesday have witnessed increased shopping activity, with Thursday and Friday becoming less popular. Non-food items were purchased most frequently on Saturdays, which was the most popular day in all editions of the study, with a significant increase in 2018 compared to 2016. The increased nonfood merchandise sales volume was a result of the nature of the goods. The decision-making process usually requires more effort in this product category, and involves, among others, comparing alternative means of satisfying the customer's needs, which translates to such purchases being postponed until a day on which they have more free time available.

\section{Weekly general food merchandise shopping schedules in different consumer groups}

In 2018, the first two days of the week were more popular as days to shop for food merchandise among respondents living in rural areas (Table 2 ). On the other hand, inhabitants of urban areas preferred Wednesday and Thursday. Friday was preferred by those living in less urbanised areas, and shopping activity was higher on Saturdays among urban residents, who also shopped more frequently on Sundays.

The analysis of income brackets (Table 2) indicates that the popularity of shopping on Mondays is inversely proportional to the respondents' level of wealth. Consumers whose income exceeded PLN 1000 shopped relatively more often on Tuesdays, and those whose income exceeded 1500 - on Wednesdays. Thursdays were most frequently chosen by those from the PLN 1001-1500 bracket.

The number of household members grew proportionally to the frequency of shopping on Mondays (Table 3), the purpose being to replenish food consumed on the preceding Sunday. It is not surprising that the largest families continued their shopping on Tuesdays, and that such families were also most likely to shop on Saturdays. Single-person households were twice as likely as other respondents to select Wednesday as their main shopping day. While Thursday was of equal importance to single and double-person 
households, families of 3-5 were significantly less likely to shop on that day, with Thursday being completely marginalised among the largest of families studied.

\section{Table 2. Preferred days for purchasing general food merchandise in $\mathbf{2 0 1 8}$ (by location and income level) (\%)}

\begin{tabular}{|c|c|c|c|c|c|c|c|c|}
\hline & \multirow[b]{2}{*}{ Total } & \multicolumn{2}{|c|}{ Location } & \multicolumn{5}{|c|}{ Income in PLN per household member } \\
\hline & & $\begin{array}{l}\text { urban } \\
\text { area }\end{array}$ & $\begin{array}{c}\text { rural } \\
\text { area }\end{array}$ & \begin{tabular}{l}
8 \\
8 \\
$\circ$ \\
\multirow{3}{*}{}
\end{tabular} & $\begin{array}{l}8 \\
0 \\
1 \\
\\
8 \\
0\end{array}$ & 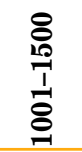 & 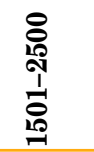 & 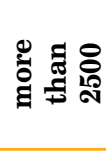 \\
\hline $\begin{array}{l}\text { Total percentage of respondents } \\
\text { customers shopping on: }\end{array}$ & 100.0 & 100.0 & 100.0 & 100.0 & 100.0 & 100.0 & 100.0 & 100.0 \\
\hline Monday & 24.4 & 23.0 & 27.0 & 40.7 & 27.1 & 23.3 & 19.1 & 20.6 \\
\hline Tuesday & 11.2 & 9.3 & 14.6 & 7.4 & 8.3 & 13.7 & 10.3 & 14.7 \\
\hline Wensday & 9.2 & 9.9 & 7.9 & 7.4 & 8.3 & 5.5 & 13.2 & 11.8 \\
\hline Thursday & 6.8 & 8.1 & 4.5 & 3.7 & 4.2 & 11.0 & 7.4 & 2.9 \\
\hline Friday & 17.6 & 17.4 & 18.0 & 11.1 & 12.5 & 19.2 & 22.1 & 17.6 \\
\hline Saturday & 29.2 & 30.4 & 27.0 & 29.6 & 37.5 & 26.0 & 26.5 & 29.4 \\
\hline Sunday & 1.6 & 1.9 & 1.1 & 0.0 & 2.1 & 1.4 & 1.5 & 2.9 \\
\hline
\end{tabular}

Source: calculations based on results of the own research.

Table 3. Preferred days for purchasing general food merchandise in $\mathbf{2 0 1 8}$ (by number of household members and gender) (\%)

\begin{tabular}{|c|c|c|c|c|c|c|c|}
\hline & \multirow[b]{2}{*}{ Total } & \multicolumn{4}{|c|}{ No. of household members } & \multicolumn{2}{|c|}{ Gender } \\
\hline & & - & N & فी & 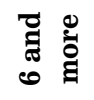 & female & male \\
\hline $\begin{array}{l}\text { Total percentage of respondents } \\
\text { customers shopping on: }\end{array}$ & 100.0 & 100.0 & 100.0 & 100.0 & 100.0 & 100.0 & 100.0 \\
\hline Monday & 24.4 & 5.6 & 18.6 & 27.3 & 29.4 & 25.6 & 22.3 \\
\hline Tuesday & 11.2 & 11.1 & 14.0 & 9.9 & 17.6 & 12.8 & 8.5 \\
\hline Wensday & 9.2 & 22.2 & 11.6 & 7.0 & 11.8 & 7.7 & 11.7 \\
\hline Thursday & 6.8 & 11.1 & 11.6 & 5.8 & 0.0 & 5.1 & 9.6 \\
\hline Friday & 17.6 & 11.1 & 9.3 & 21.5 & 5.9 & 18.6 & 16.0 \\
\hline Saturday & 29.2 & 33.3 & 32.6 & 27.3 & 35.3 & 28.8 & 29.8 \\
\hline Sunday & 1.6 & 5.6 & 2.3 & 1.2 & 0.0 & 1.3 & 2.1 \\
\hline
\end{tabular}

Source: calculations based on results of the own research. 
Women were more likely than men to prefer to shop on Mondays, Tuesdays and Fridays, with men preferring Wednesdays and Thursdays to a greater degree (Table 3). While both genders were equally likely to shop on Saturdays, men purchased food merchandise twice as often on Sundays. This may be a result of making food purchases while visiting filling stations, which also operate on Sundays.

The age of respondents did not clearly determine the day on which they preferred to shop (Table 4). The youngest respondents were relatively most likely to purchase food merchandise on Mondays. Monday was slightly less popular among respondents from the oldest age bracket, and significantly less popular among the remaining groups. Consumers above 50 years of age were relatively most likely to make purchases on Tuesdays. Thursdays were not popular among young respondents. The popularity of Fridays was inversely proportional to the age of the respondents, but this trend was broken by the oldest age group, in which case purchases were made less frequently compared to 15-25-year-olds. Saturday was selected as the main shopping day by a similar percentage of respondents $(27.9-31.7 \%)$ in all age brackets.

\section{Table 4. Preferred days for purchasing general food merchandise in $\mathbf{2 0 1 8}$ (by age and education) (\%)}

\begin{tabular}{|c|c|c|c|c|c|c|c|c|}
\hline & \multirow{2}{*}{ Total } & \multicolumn{4}{|c|}{ Age } & \multicolumn{3}{|c|}{ Education } \\
\hline & & 15-25 & 26-35 & 36-50 & $\begin{array}{c}\text { older } \\
\text { than } 50\end{array}$ & $\begin{array}{l}\text { primary or } \\
\text { vocational }\end{array}$ & secondary & tertiary \\
\hline $\begin{array}{l}\text { Total percentage } \\
\text { of respondents customers } \\
\text { shopping on: }\end{array}$ & 100.0 & 100.0 & 100.0 & 100.0 & 100.0 & 100.0 & 100.0 & 100.0 \\
\hline Monday & 24.4 & 33.1 & 10.4 & 12.2 & 27.9 & 23.7 & 29.5 & 19.6 \\
\hline Tuesday & 11.2 & 11.0 & 10.4 & 9.8 & 14.0 & 15.8 & 11.4 & 9.3 \\
\hline Wensday & 9.2 & 8.5 & 14.6 & 7.3 & 7.0 & 10.5 & 8.6 & 9.3 \\
\hline Thursday & 6.8 & 2.5 & 10.4 & 12.2 & 9.3 & 13.2 & 3.8 & 7.5 \\
\hline Friday & 17.6 & 15.3 & 18.8 & 26.8 & 14.0 & 13.2 & 13.3 & 23.4 \\
\hline Saturday & 29.2 & 28.0 & 31.3 & 31.7 & 27.9 & 23.7 & 31.4 & 29.0 \\
\hline Sunday & 1.6 & 1.7 & 4.2 & 0.0 & 0.0 & 0.0 & 1.9 & 1.9 \\
\hline
\end{tabular}

Source: calculations based on results of the own research. 
Those possessing secondary education most frequently purchased food merchandise on Mondays (Table 4). The level of education was inversely proportional to the number of customers who preferred to shop for such products on Tuesdays, and was directly proportional to the percentage of customers who shopped on Fridays. Respondents with secondary education and above were more likely to shop on Saturdays.

\section{Weekly non-food merchandise shopping schedules in different consumer groups}

When comparing respondent behaviours regarding food and non-food merchandise in 2018, it is important to note the lesser diversity in declarations related to non-food products among urban and rural residents (Table 5). To a similar degree, rural and urban respondents selected Mondays (10.1 and 9.9), Wednesdays (11.2 and 11.8), Fridays (18.0 and 19.3) and Saturdays (44.9 and 45.3) as their shopping days. Differences were slightly more pronounced in the case of Tuesdays, which were more popular among urban residents, and Fridays, which were more popular among rural inhabitants.

\section{Table 5. Preferred days for purchasing non-food merchandise in $\mathbf{2 0 1 8}$} (by location and income level) (\%)

\begin{tabular}{|c|c|c|c|c|c|c|c|c|}
\hline & \multirow[b]{2}{*}{ Total } & \multicolumn{2}{|c|}{ Location } & \multicolumn{5}{|c|}{$\begin{array}{l}\text { Income in PLN per household } \\
\text { member }\end{array}$} \\
\hline & & $\begin{array}{c}\text { urban } \\
\text { area }\end{array}$ & $\begin{array}{c}\text { rural } \\
\text { area }\end{array}$ & 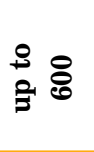 & $\begin{array}{l}8 \\
8 \\
\frac{1}{1} \\
8 \\
8\end{array}$ & $\frac{10}{1}$ & 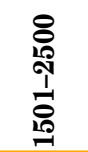 & 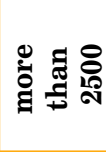 \\
\hline $\begin{array}{l}\text { Total percentage } \\
\text { of respondents customers } \\
\text { shopping on: }\end{array}$ & 100.0 & 100.0 & 100.0 & 100.0 & 100.0 & 100.0 & 100.0 & 100.0 \\
\hline Monday & 10.0 & 9.9 & 10.1 & 11.1 & 4.2 & 8.2 & 14.7 & 11.8 \\
\hline Tuesday & 7.6 & 8.1 & 6.7 & 7.4 & 4.2 & 6.8 & 11.8 & 5.9 \\
\hline Wensday & 11.6 & 11.8 & 11.2 & 14.8 & 10.4 & 12.3 & 10.3 & 11.8 \\
\hline Thursday & 5.2 & 4.3 & 6.7 & 3.7 & 6.3 & 6.8 & 5.9 & 0.0 \\
\hline Friday & 18.8 & 19.3 & 18.0 & 14.8 & 20.8 & 19.2 & 16.2 & 23.5 \\
\hline Saturday & 45.2 & 45.3 & 44.9 & 48.1 & 52.1 & 45.2 & 39.7 & 44.1 \\
\hline Sunday & 1.6 & 1.2 & 2.2 & 0.0 & 2.1 & 1.4 & 1.5 & 2.9 \\
\hline
\end{tabular}

Source: calculations based on results of the own research. 
An analysis of the income brackets (Table 5) indicates that Mondays were relatively less popular for non-food purchases among respondents whose income ranges between PLN 1501 and 2500, who are in turn more likely than other brackets to make such purchases on Tuesdays. A similar percentage of respondents from every income bracket (between 10.3 and 14.8\%) made non-food purchases on Wednesdays, and Thursdays were similarly popular for non-food merchandise among respondents whose income ranged between PLN 601 and 2,500. Customers whose income per person did not exceed PLN 600 were half as likely to make purchases on Thursdays, and the wealthiest respondents did not shop for non-food merchandise at all on that day.

\section{Table 6. Preferred days for purchasing non-food merchandise in $\mathbf{2 0 1 8}$}

(by number of household members and gender) (\%)

\begin{tabular}{|c|c|c|c|c|c|c|c|}
\hline & \multirow[b]{2}{*}{ Total } & \multicolumn{4}{|c|}{ No. of household members } & \multicolumn{2}{|c|}{ Gender } \\
\hline & & - & N & فे & 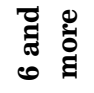 & female & male \\
\hline $\begin{array}{l}\text { Total percentage of respondents } \\
\text { customers shopping on: }\end{array}$ & 100.0 & 100.0 & 100.0 & 100.0 & 100.0 & 100.0 & 100.0 \\
\hline Monday & 10.0 & 0.0 & 11.6 & 11.0 & 5.9 & 10.9 & 8.5 \\
\hline Tuesday & 7.6 & 11.1 & 11.6 & 5.8 & 11.8 & 6.4 & 9.6 \\
\hline Wensday & 11.6 & 16.7 & 9.3 & 11.0 & 17.6 & 9.0 & 16.0 \\
\hline Thursday & 5.2 & 5.6 & 4.7 & 5.8 & 0.0 & 6.4 & 3.2 \\
\hline Friday & 18.8 & 5.6 & 20.9 & 20.9 & 5.9 & 18.6 & 19.1 \\
\hline Saturday & 45.2 & 55.6 & 41.9 & 43.6 & 58.8 & 48.1 & 40.4 \\
\hline Sunday & 1.6 & 5.6 & 0.0 & 1.7 & 0.0 & 0.6 & 3.2 \\
\hline
\end{tabular}

Source: calculations based on results of the own research.

Non-food items were most frequently purchased on Mondays by customers from 2-5 person families (Table 6). Members of larger families were less likely to make purchases then (5.9\%), and no single-person household declared Monday as their main shopping day. A similar percentage (approx. 11.5\%) of respondents across all household size subgroups made non-food purchases on Tuesday, the only exception being 3-5-person families, where the percentage was half the average. 
Wednesday was the most popular day among respondents from the largest families, as well as single-person households. Approximately $5 \%$ of respondents from 1-5 person households made purchases on Thursdays, while families numbering at least 6 members did not shop on Thursdays at all. Single-person households and those numbering 6 and more members were significantly less likely than 2-5-person households to purchase non-food items on Fridays, and were significantly more likely than other size subgroups to make such purchases on Saturdays. Singleperson households were most likely to make non-food purchases on Sundays.

Women purchased non-food items on Mondays, Thursdays and Saturdays more frequently than men, who preferred Tuesdays, Wednesdays and Fridays. Men were also more likely to visit shops offering non-food merchandise which are open on Sundays (Table 6).

Monday was the most popular shopping day among respondents between 36 and 50 years of age, and the least popular in the 26-35 age group, in which Tuesday was also an unpopular day for shopping. On Wednesdays, Thursdays and Saturdays, customers aged between 36 and 50 were relatively unlikely to purchase non-food merchandise, and were much more likely than other subgroups to shop on Fridays. Saturday was the most popular day among the youngest respondents (Table 7).

Interest in shopping on Monday and Wednesday was inversely proportional to the level of education (Table 7). Despite there being no linear trend, it is important to note that Tuesday was the least popular day for purchasing non-food merchandise among those with higher education, who were more likely to postpone such purchases until the end of the week, most frequently Friday and Saturday, though in the latter case, they were less likely to do so than respondents possessing secondary education. In addition, tertiary education degree holders were most likely to patronise non-food retail outlets on trading Sundays. 


\section{Table 7. Preferred days for purchasing non-food merchandise in $\mathbf{2 0 1 8}$ (by age and education) (\%)}

\begin{tabular}{l|r|r|r|r|r|r|r|r}
\hline & & \multicolumn{4}{|c|}{ Age } & \multicolumn{3}{c}{ Education } \\
\cline { 3 - 9 } & Total & $\mathbf{1 5 - 2 5}$ & $\mathbf{2 6 - 3 5}$ & $\mathbf{3 6 - 5 0}$ & $\begin{array}{l}\text { older } \\
\text { than 50 }\end{array}$ & $\begin{array}{l}\text { primary or } \\
\text { vocational }\end{array}$ & secondary & tertiary \\
\hline Total percentage & & & & & & & & \\
of respondents customers & & & & & & & & \\
shopping on: & 100.0 & 100.0 & 100.0 & 100.0 & 100.0 & 100.0 & 100.0 & 100.0 \\
Monday & 10.0 & 10.2 & 4.2 & 14.6 & 11.6 & 13.2 & 9.5 & 9.3 \\
Tuesday & 7.6 & 9.3 & 2.1 & 7.3 & 9.3 & 7.9 & 8.6 & 6.5 \\
Wensday & 11.6 & 12.7 & 12.5 & 4.9 & 14.0 & 15.8 & 14.3 & 7.5 \\
Thursday & 5.2 & 3.4 & 12.5 & 2.4 & 4.7 & 7.9 & 3.8 & 5.6 \\
Friday & 18.8 & 15.3 & 18.8 & 31.7 & 16.3 & 18.4 & 15.2 & 22.4 \\
Saturday & 45.2 & 48.3 & 43.8 & 39.0 & 44.2 & 36.8 & 48.6 & 44.9 \\
Sunday & 1.6 & 0.8 & 6.3 & 0.0 & 0.0 & 0.0 & 0.0 & 3.7 \\
\hline
\end{tabular}

Source: calculations based on results of the own research.

An analysis of the presented research result utilising a chi-squared test for the purpose of verifying whether statistically significant differences actually exist in the distribution for the defined subgroups also renders it possible to determine the existence of such differences (for $\alpha=0.05$ ) in the distribution of shopping across individual days of the week in 2014, 2016 and 2018, both in the case of food and non-food merchandise. This level of statistical significance is insufficient to observe this level of diversity when categorising according to the defined demographical, social or economic features, which serve an informational purpose only. Thus, it is valid to claim that the analysed phenomenon is more diverse across time than across the presented subgroups. 


\section{Conclusions}

The implementation of the Act on limiting trade on Sundays, holidays and certain other days on 10 January 2018 resulted, on the one hand, in a number of protests by enterprises, who were forced to reorganise their work schedules to take into account the legislative changes, and in opposition from customers, who were concerned about their convenient access to retail outlets offering general food and non-food merchandise, on the other. The numerous discussions and awareness initiatives which took place before the act entered into force allowed the demand to adapt to the new conditions. In line with the premise behind the new legislation, the number of customers doing their main shopping of the week on Sundays decreased. Purchases of food merchandise shifted to Mondays and Tuesdays of the following week, which is contrary to the expectation that preceding Saturdays would be chosen instead. This may indicate greater interest among customers in catering services, which were not affected by the legislation, as well as a degree of pragmatism customers would rather avoid the inconvenience of crowded shops and queues on Saturdays. Saturday has become the day on which the majority of customers shop for non-food items. No longer able to make such purchases on Sundays, a negligible percentage of consumers migrated to Mondays, Tuesdays and Wednesdays. In 2018, the group which displayed the most attachment to shopping for food merchandise on Sundays were urban men aged 26-35, who had at least secondary education, whose income exceeded PLN 2,500 and whose households numbered only 1 person. For non-food items, this statistic shifts slightly towards higher education and rural areas. The changes observed over time were more statistically significant than the differences identified in 2018 among respondents belonging to the diverse subgroups defined for the purpose of the analysis.

The conducted research allows to conclude that legislation can significantly influence both consumers behaviours and the way in which retailers should organise their activities. Recommendation for 
retail trade enterprises may, however, differ concerning type of their assortment. Taking into account the analysed issue, it is suggested for food retailers to engage their labour resources to wider extend on Mondays and Tuesdays following the Sunday without trade, while non-food retailers should shift the employees to Saturday work. Moreover, some conclusions may be specified concerning marketing activities of such retailers who are allowed to trade on Sundays. To successfully run their businesses they should focus on meeting the needs of their typical clients: single, relatively wealthy and educated. Nevertheless, considering negligible differences between consumers groups, the offer should be accessible and attractive for the others as well.

\section{References}

1. Adamiec, J., Grodzka, D. (2017). Społeczne uwarunkowania handlu w niedziele. Infos, 1(224), 1-4.

2. Drobny, P. (2015). Zakaz pracy w niedzielę jako problem granic ekonomii. Studia Ekonomiczne, 210, 108-117.

3. Dylus, A. (2013). Ochrona prawna niedzieli. Próba uzasadnienia. Prakseologia, 154, 187-199.

4. Jękot, A. (2018). Ograniczenie i zakaz handlu w niedziele w opinii konsumentów. Zeszyty Naukowe Wyższej Szkoły Ekonomiczno-Społecznej w Ostrołęce, 3(30), 9-22.

5. Strzała, M., Grygutis, J. (2018). Założenia aksjologiczne ustawy o ograniczeniu handlu w niedzielę i święta. Studia z Zakresu Prawa Pracy i Polityki Spotecznej, 25(1), 1-18; DOI: 10.4467/25444654SPP. 18.001.8273.

6. Szromnik, A. (2017a). Handel i zakupy w niedzielę w opinii społecznej — studium porównawcze (cz. I). Handel Wewnętrzny, 3(368) t. II, 409-422.

7. Szromnik, A. (2017b). Handel i zakupy w niedzielę w opinii społecznej — studium porównawcze (cz. II). Handel Wewnętrzny, 4(369) t. I, 180-199.

8. Ustawa z dnia 10 stycznia 2018 r. o ograniczeniu handlu w niedziele i święta oraz w niektóre inne dni, Dz. U. z 2018 r. poz. 305. 
Piotr Cyrek, PhD, University of Rzeszów, Collegium of Social Sciences, Institute of Economics and Finance, Poland - researcher at the University of Rzeszów since 2001. Holds a Doctoral Degree in Economics. Research interests focus on consumers behaviour connected with purchasing decisions at the FMCG market. Simultaneously they include efficiency issues of organizational strategies in retail trade enterprises. 